\title{
Epidemiologic and Economic Analysis of Rapid Antiretroviral Therapy Initiation with Bictegravir/Emtricitabine/Tenofovir Alafenamide in Spain
}

\author{
Vicente Estrada ${ }^{1} \cdot$ Miguel Górgolas $^{2} \cdot$ José A. Peña $^{3} \cdot$ Elena Tortajada $^{4} \cdot$ Antonio Castro $^{5} \cdot$ María Presa $^{6}$ (D) \\ Itziar Oyagüez ${ }^{6}$
}

Accepted: 10 January 2022 / Published online: 5 February 2022

(c) The Author(s) 2022

\begin{abstract}
Objective This study aimed to assess the potential epidemiological and economic impact of rapid initiation of human immunodeficiency virus (HIV) treatment with bictegravir/emtricitabine/tenofovir alafenamide (B/F/TAF) on HIV transmission compared with the current initiation observed in clinical practice in Spain.

Methods A transmission model was adapted to estimate the cumulative HIV infection incidence and potential cost savings based on the number of HIV infections prevented among men who have sex with men, heterosexual males and females, and people who inject drugs (PWID) over a 20-year time horizon. The analysis compared rapid antiretroviral therapy (ART) initiation with B/F/TAF ( 9 days from diagnosis until treatment initiation) versus current ART initiation practice (with an average of 35 days from diagnosis to treatment). People living with HIV were distributed according to their treatment status. Risk for transmission was assigned to undiagnosed, diagnosed in care and not receiving ART, and receiving ART but virally unsuppressed, which was estimated by sexual contact, needles and syringes shared among PWID, state of HIV infection, and ART use.

Results In the base-case analysis, rapid ART initiation with B/F/TAF is expected to prevent 992 new HIV infections over the next 20 years compared with current ART initiation practices. Considering the lifetime costs of treating HIV infection, the reduction in HIV incidence could result in potential cost savings of $€ 323$ million.

Conclusions These results suggest that rapid ART initiation with B/F/TAF in newly diagnosed patients with HIV is a highvalue strategy for the Spanish National Health System and society, reducing HIV incidence and thereby reducing future related direct and indirect costs of care.
\end{abstract}

María Presa

mpresa@porib.com

1 Department of Infectious Diseases, Hospital Clínico San Carlos, Madrid, Spain

2 Department of Infectious Diseases, Hospital Universitario Fundación Jiménez Díaz, Madrid, Spain

3 Pharmacy Department, Hospital Clínico San Carlos, Madrid, Spain

4 Pharmacy Department, Hospital Universitario Fundación Jiménez Díaz, Madrid, Spain

5 Gilead Sciences, Madrid, Spain

6 Pharmacoeconomics and Outcomes Research Iberia, $\mathrm{P}^{o}$ Joaquín Rodrigo 4- letra I, Pozuelo de Alarcón, 28224 Madrid, Spain 


\section{Key Points for Decision Makers}

Rapid antiretroviral therapy (ART) initiation with bictegravir/emtricitabine/tenofovir alafenamide on day 9 after human immunodeficiency virus (HIV) diagnosis could prevent 992 potential HIV infections over the next 2 decades compared with the current ART initiation practices on day 35 .

The reduction in HIV incidence with rapid ART initiation versus current ART initiation could result in $€ 323$ million potential savings for the Spanish National Health System and society over the next 2 decades.

Clinical benefits and savings could be achieved if the period between HIV diagnosis and ART initiation is reduced.

\section{Introduction}

Recent research efforts have led to important advances in the treatment and prevention of human immunodeficiency virus (HIV) and hence acquired immunodeficiency syndrome (AIDS), thereby decreasing the worldwide incidence of infection. An estimated 1.7 million individuals worldwide acquired HIV in 2019, marking a 23\% decline in new HIV infections since 2010 [1].

AIDS-related mortality has reduced from the peak observed in 2006, with a decrease from 1.95 million deaths around the world to 0.95 million deaths observed in 2017 [2]. The availability of increasingly effective antiretroviral therapies (ARTs) developed during the last 2 decades has been one of the key interventions that have contributed to this continued decline in global AIDS mortality.

Access to effective ART has been due in part to the evolution of international strategies, most of which are integrated at the United Nations Joint Programme on HIV/AIDS (UNAIDS). The latest data published by UNAIDS reported that in 2019, almost 38.0 million people were living with HIV (PLWH) worldwide, and approximately 26.0 million were able to access ART as of the end of June 2020 [1]. Increasing the proportion of PLWH under treatment is one of the priorities established by UNAIDS [3], which defined the three following main targets in the fight against HIV/ AIDS for 2030 [4]: 95\% of all PLWH are aware of their HIV status; 95\% of all people with diagnosed HIV infection are treated with sustained ART; and $95 \%$ of all people receiving ART reach viral suppression.
The aim of ART is to achieve an undetectable plasma viral load, leading to a state of viral suppression that enables immune recovery and controls disease progression by reducing the risk of developing AIDS. There is strong evidence that PLWH who are taking effective ART and whose level of HIV is suppressed to maintain an undetectable viral load $(<50$ copies $/ \mathrm{mL})$ will not transmit HIV infection by sexual contact [5]; therefore, stronger efforts should be made to ensure that PLWH can access ART as soon as they are diagnosed. Late diagnosis means individuals have delayed access to effective ART, and both factors are linked to the further expansion of the epidemic as well as to a greater risk for developing AIDS and an increased risk of mortality compared with those who are diagnosed soon after infection and who have access to effective treatment early on $[6,7]$.

The criteria for ART initiation have varied depending on the availability of ART. It was initially recommended for PLWH based on levels of CD4 cells [8, 9], and subsequently, by 2015 [10], it was recommended for all PLWH irrespective of their CD4 count, which was supported by the effectiveness of early ART studies reported on in clinical trials [11]. Two large, randomized trials (TEMPRANO and START) reported evidence supporting that early ART initiation in the course of HIV infection resulted in both public health benefits attributable to reduced transmission and individuallevel benefits of improved health. In short, it was stated that ART should be initiated as soon as possible after the diagnosis of HIV [12]. In line with these conclusions, the World Health Organization (WHO) [13] recommended that adapted protocols for care, such as HIV screening, prophylaxis, rapid ART initiation and intensive adherence interventions, should be offered to PLWH. Within the context of the strategy of extended treatment, the WHO strongly recommended that rapid ART initiation, i.e. within 7 days of HIV diagnosis, should be offered to PLWH following a confirmed diagnosis and clinical assessment [13].

In recent decades, many antiretroviral drugs have been developed and approved as therapies for PLWH $[14,15]$. ART with combinations of two or three drugs constitutes the treatment of choice for chronic HIV infection [9]. Among the recommended first-line regimens for ART-naïve PLWH, the European AIDS Clinical Society (EACS) recommends options consisting of two nucleoside reverse transcriptase inhibitors [NRTIs] in combination with an unboosted integrase strand transfer inhibitor [INSTI] [16]. Until recently, this drug class comprised first-generation agents, such as raltegravir and elvitegravir, or the second-generation agent dolutegravir.

The latest incorporation to the second-generation group of INSTIs was bictegravir, which was approved as a oncedaily, single-treatment regimen, in combination with emtricitabine and tenofovir alafenamide (B/F/TAF) [17]. Among the preferred regimens, the EACS favours those containing 
Fig. 1 Model structure. $A R T$ antiretroviral therapy, $L T F U$ lost to follow-up, PLWH people living with HIV

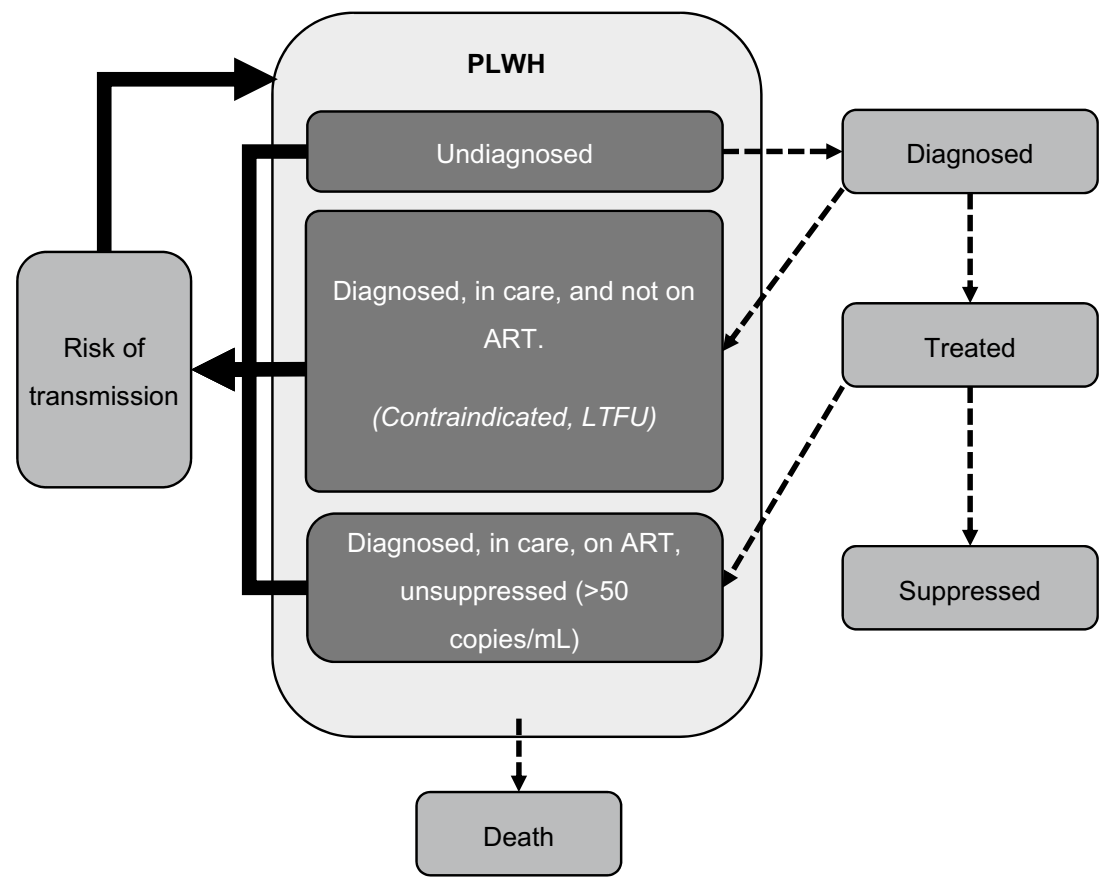

dolutegravir or bictegravir as a third agent, and the 2020 GeSIDA/Spanish National AIDS Plan recommends bictegravir as a preferent treatment [18].

$\mathrm{B} / \mathrm{F} / \mathrm{TAF}$ is a treatment option for individuals co-infected with HIV and hepatitis B virus (HBV); this treatment avoids the need to wait for the results of HBV testing before initiating treatment, does not require baseline HLA-B*5701 testing before initiating treatment and does not trigger hypersensitivity reactions. Therefore, $\mathrm{B} / \mathrm{F} / \mathrm{TAF}$ has been shown to meet all the criteria for rapid ART initiation.

In Spain, in recent years, despite access to effective ART, the incidence of HIV, far from being reduced, has remained stable. According to the Spanish System of Information on New Diagnoses of HIV Infection, 3244 and 2698 new diagnoses were recorded in 2018 and 2019, respectively [19, 20]. Because people with unsuppressed viral loads contribute to the incidence of new HIV infections every year due to their risk for transmission (by sexual contact or by sharing needles and syringes for injected drugs), additional strategies are required to reduce the number of new infections in Spain.

The present study aimed to evaluate, through a transmission model, the potential epidemiologic and economic impact of rapid treatment initiation with B/F/TAF on HIV transmission among heterosexuals, men who have sex with men (MSM) and people who inject drugs (PWID) in Spain compared with the current ART initiation observed in clinical practice.

\section{Material and Methods}

The effect of early therapy on disease dissemination by reducing new HIV cases was derived by comparing two different scenarios: the current clinical practice for ART initiation following an HIV infection diagnosis, and a new strategy based on early therapy initiation with B/F/TAF.

\subsection{Modelling Approach}

A dynamic transmission model for HIV was customized to the Spanish setting to assess the impact of the new treatment strategy on the number of cumulative HIV infections over a 20 -year time horizon. The model was design as a Markov tree with a 1-year cycle with associated transition probabilities (specific for each subgroup of population) between each state. These probabilities included a dynamically varying transition probability, estimated by an exponential distribution, to obtain the rate of new infections based on the number of patients who were at risk of transmitting. Tunnel states were used to account for average durations greater than one cycle. The probability of new infections was based on the number of patients among three groups: undiagnosed patients, untreated patients, and patients with detectable viral load (> 50 copies/mL) (Fig. 1).

The population assessed in the model included the three key subgroups considered by the WHO as those with the highest risk of exposure to HIV: heterosexual males and females, MSM and PWID, all of which were modelled separately. Because human migration patterns are complex, there is a significant barrier to the collection of accurate data 
relating to these populations over time. Therefore, migrant HIV transmission was not specifically captured in the model and it was assumed that data pertaining to the included population subgroups would be inclusive of migrants. Sexual behaviours in heterosexuals and MSM subgroups were captured by propagation parameters, estimating the new infections followed a Poisson's process [new infections $=X^{*}$ $\left(1-(1-\text { average transmission risk per act })^{\text {Propagation factor }}\right.$. For PWID, the risk of transmission was based on the risk of being exposed to infected equipment and the number of non-infected PWID (new infections $=$ non infected $*$ prevalence $*$ percentage of equipment sharing * $(1-(1-$ average

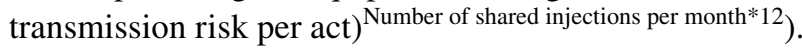

Propagation factor that reproduced the incidence observed by the European Centre for Disease Prevention and Control (ECDC) in 2016 [21] was estimated by applying the model on the historic data. New HIV infections estimated by the model at the beginning of the simulation (3215 cases) were compared with national HIV figures in the year 2019 (3264 cases) [22] to check reproducibility.

\subsection{Model Parameters}

The model, inputs and assumptions considered in the present analysis were validated by an advisory board composed of four physicians who were experts in the management of HIV. In the consensus process, experts made decisions by agreement, working together to find a mutually acceptable value.

In the current clinical practice scenario, the average time from diagnosis to ART initiation was fixed at 35 days, derived from a market study (data on file) developed in Spain that assessed the period from HIV infection diagnosis to ART initiation in the second quarter of 2019. This parameter was validated by an expert panel and represents a conservative approach, taking into account that the average time from diagnosis to ART initiation in a Spanish cohort of naïve HIV-infected patients included in the Research Network on HIV/AIDS (CoRIS) was 44 days [23]. The average time to $\mathrm{B} / \mathrm{F} / \mathrm{TAF}$ initiation in the early therapy scenario was established at 9 days in consideration of the expert panel's opinion.
The distribution of the third component of the ART regimen, provided and validated by the expert panel as representative of the Spanish setting, was $77.0 \%$ of INSTIs, 3.0\% of non-nucleoside reverse transcriptase inhibitors (NNRTIs), and $20.0 \%$ of protease inhibitors (PIs). These proportions are in line with current clinical practice and with the GeSIDA/ Spanish National AIDS Plan, which recommends initiating combination therapy with an INSTI due to its high efficacy, low risk of toxicity and rapid virologic suppression [18]. The dynamics of viral load suppression per week and the type of ART prescribed, as detailed in Table 1, were derived from data reported in clinical trials [24-31].

The HIV lifetime cost, including HIV-direct and -indirect costs, in Spain $(€ 325,408)$ was identified in the literature [32] and was updated from 2015 to 2020 values.

The total numbers of heterosexual males and females were obtained from the Spanish Statistics National Institute [33], adjusting the male population with the MSM and PWID population. MSM figures were derived from UNAIDS country factsheets [34], and PWID figures were derived from the Spanish Observatory of Drugs and Additions [35]. Total numbers and other inputs related to these population subgroups are detailed in Table 2.

HIV prevalence in Spain was established at 151,400, according to the most recent data [36]. The distribution of prevalence among the population subgroups was performed according to HIV incidence data published by the Spanish Ministry of Health, after the deletion of maternal and transfusion HIV transmission (314 cases) (Table 2) [19].

The HIV diagnosis for the current practice was fixed at $87.0 \%$ of the total PLWH [36]. In the absence of data on specialist derivation in the national and European reports, figures related to HIV cases already under treatment $(97.3 \%$ of those diagnosed with HIV), as reported by the most recent data actualization for Spain [36], were also assumed for the proportion of cases in care. Viral suppression was observed in $90.4 \%$ of PLWH [36].

Loss to follow-up, definitive (7.34\%) [37] or for 1 year (6.01\%) [37], was applied to the incidence data, reducing the number of patients in care and also the number of treated patients. An annual death rate for each subgroup of
Table 1 Dynamics of viral suppression per ART type and weeks of therapy

\begin{tabular}{llrrrrrr}
\hline ART & \multicolumn{7}{l}{ Weeks of Therapy } \\
\cline { 2 - 8 } & 0 & \multicolumn{1}{c}{2} & \multicolumn{1}{c}{4} & 12 & 24 & 36 & 48 \\
\hline INSTIs & 0.1 & 30.4 & 62.7 & 86.3 & 91.3 & 90.9 & 91.2 \\
NNRTIs & 0.0 & 7.2 & 16.8 & 63.8 & 86.7 & 84.9 & 85.0 \\
PIs & 0.0 & 1.4 & 9.0 & 58.0 & 86.8 & 86.1 & 88.2 \\
B/F/TAF [26, 27] & 0.0 & 38.6 & 77.2 & 96.0 & 95.8 & 93.9 & 91.9 \\
\hline
\end{tabular}

Data are expressed as percentages

$A R T$ antiretroviral therapy, B/F/TAF bictegravir/emtricitabine/tenofovir alafenamide, INSTIs integrase strand transfer inhibitors, NNRTIs non-nucleoside reverse transcriptase inhibitors, PIs protease inhibitors 
Table 2 Population inputs

\begin{tabular}{|c|c|c|c|c|}
\hline \multirow[t]{3}{*}{ Parameter } & \multicolumn{4}{|l|}{ Subgroups } \\
\hline & \multicolumn{2}{|l|}{ Heterosexuals } & \multirow[t]{2}{*}{ MSM } & \multirow[t]{2}{*}{ PWID } \\
\hline & Males & Females & & \\
\hline Total population size [33-35] & $22,156,305^{\mathrm{a}}$ & $24,081,617^{b}$ & 890,200 & 13,136 \\
\hline Prevalence of HIV cases $[19,36]$ & 24,619 & 20,412 & 94,945 & 5454 \\
\hline Incidence of HIV cases [19] & 548 & 454 & 2113 & 121 \\
\hline Annual death rate [38] & 28.5/1000 inhabitants & $13.6 / 1000$ inhabitants & 5.1/1000 inhabitants & $\begin{array}{l}\text { 38.2/1000 } \\
\text { inhabit- } \\
\text { ants }\end{array}$ \\
\hline $\begin{array}{l}\text { Per-act transmission probability HIV- } \\
\text { positive under ART unsupressed }{ }^{\text {c }} \text { - } \\
\text { week } 0[39]\end{array}$ & 0.00159 & $0.00318^{\mathrm{d}}$ & 0.01767 & $0.00963^{\mathrm{d}}$ \\
\hline $\begin{array}{l}\text { Per-act transmission probability HIV- } \\
\text { positive under ART unsupressed }{ }^{\text {c }}- \\
\text { weeks } 2-48 \text { [39] }\end{array}$ & 0.00010 & $0.00021^{\mathrm{d}}$ & 0.00134 & $0.00072^{\mathrm{d}}$ \\
\hline
\end{tabular}

$A R T$ antiretroviral therapy, $H I V$ human immunodeficiency virus, $M S M$ men who have sex with men, $P W I D$ people who inject drugs

${ }^{\text {a }}$ Data resulting after deleting the number of MSM and male PWID from the total figure

${ }^{b}$ Data resulting after deleting the number of female PWID from the total figure

c $>50$ copies $/ \mathrm{mL}$

${ }^{\mathrm{d}}$ Assumption

the population was applied to the yearly number of patients in medical follow-up [38].

The HIV transmission probability was modelled for each of the subgroups according to scientific published evidence [39]. Given the lack of some data in the literature, it was assumed that the transmission in HIV-infected females with $>50$ copies/mL was double that observed in heterosexual males, and the transmission in PWID females was the average between transmission observed in PWID and heterosexual males. Specifically, for the PWID subgroup, it was considered that $15.3 \%$ [40] of people in that group show risk behaviours (needle or syringe sharing during the injection process) an average of 2.7 times per month [41] and that seroconversion due to these risk behaviours is $0.8 \%$ [42].

\subsection{Sensitivity Analyses}

One-way sensitivity analyses (OWSAs) were carried out to test the model's robustness. The values of the following parameters varied in each analysis: time horizon (10 years), average time to ART initiation in current practice (44 days from HIV diagnosis, according to CoRIS, and 25 days as an alternative scenario), average time to $\mathrm{B} / \mathrm{F} / \mathrm{TAF}$ initiation in the early therapy strategy (7 days from HIV diagnosis), HIV lifetime cost $( \pm 25 \%$ and estimation from various sources [43-45]), viral suppression for INSTIs per week of treatment (assuming efficacy of B/F/TAF) and distribution of the third component of the ART regimen (49.8\%, INSTIs; $25.4 \%$, NNRTIs; and $24.8 \%$, PIs), according to the Spanish surveillance system referred to as the 'Hospital survey of patients infected with HIV' [46].

\section{Results}

The model estimated that 47,399 HIV infections would occur in a 20 -year time horizon with continuation of the current clinical practice, where ART is initiated following an average of 35 days after an HIV-infection diagnosis. In the scenario representing an early initiation with $\mathrm{B} / \mathrm{F} / \mathrm{TAF}$ at day 9 after diagnosis, the number of HIV cases over the same period would be 46,407 . The strategy of rapid ART initiation with $\mathrm{B} / \mathrm{F} / \mathrm{TAF}$ would protect $992(-2.09 \%)$ patients over the same 20-year period (Fig. 2).

By subgroup analysis, $71.41 \%$ of the prevented cases corresponded to MSM, $26.88 \%$ to heterosexuals, and the remaining $1.71 \%$ to PWID. The detailed number of infections per HIV testing strategy is shown in Table 3.

Cumulative costs were estimated at $€ 15,424$ million for the current clinical practice strategy and $€ 15,101$ million for early treatment initiation with the B/F/TAF strategy. Compared with the current treatment strategy observed in clinical practice, the reduction in HIV incidence associated with the implementation of early treatment initiation with $\mathrm{B} / \mathrm{F} / \mathrm{TAF}$ would result in potential savings for the Spanish National Health System and society of almost $€ 323$ million over the next 2 decades. 
Fig. 2 Cumulative HIV cases avoided with rapid $\mathrm{B} / \mathrm{T} / \mathrm{TAF}$ therapy initiation versus current clinical practice along the time horizon. HIV human immunodeficiency virus

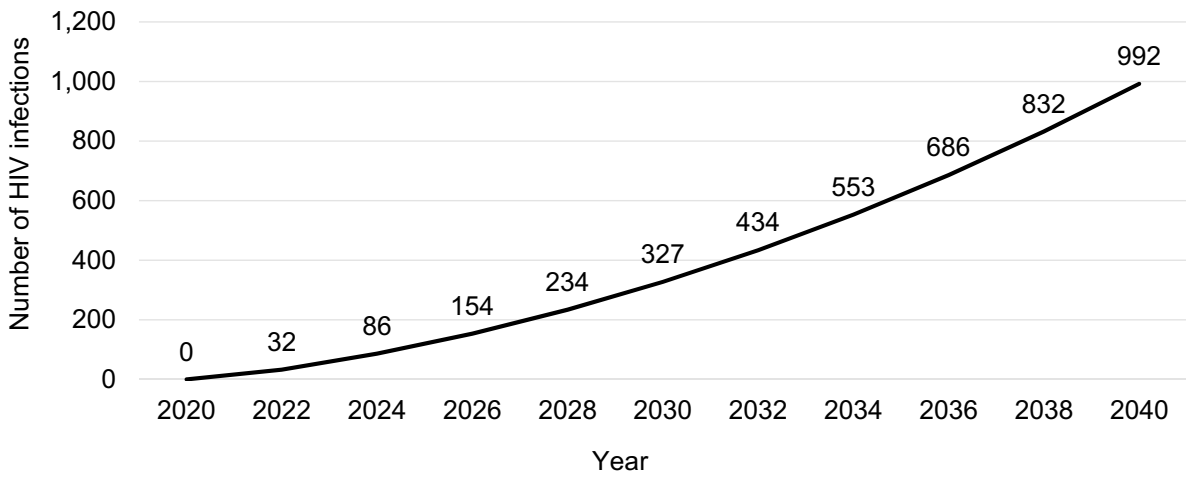

\begin{tabular}{|c|c|c|c|}
\hline \multirow[t]{2}{*}{ Subgroup } & \multicolumn{2}{|c|}{ Number of HIV infections } & \multirow{2}{*}{$\begin{array}{l}\text { HIV infections prevented with early } \\
\text { therapy strategy vs. current practice } \\
{[n(\%)]}\end{array}$} \\
\hline & Current practice & $\begin{array}{l}\text { Early } \mathrm{B} / \mathrm{T} / \mathrm{TAF} \\
\text { therapy initiation }\end{array}$ & \\
\hline Heterosexuals & 13,038 & 12,771 & $267(-2.09 \%)$ \\
\hline MSM & 33,175 & 32,466 & $709(-2.18 \%)$ \\
\hline PWID & 1187 & 1170 & $17(-1.45 \%)$ \\
\hline
\end{tabular}

B/T/TAF bictegravir/emtricitabine/tenofovir alafenamide, HIV human immunodeficiency virus, MSM men who have sex with men, $P W I D$ people who inject drugs
Table 3 HIV cases by subgroup and strategy in the 20-year time horizon need to reinforce the relevance of the conditions that indicate early ART initiation. In Spain, a cross-sectional survey carried out in 19 hospitals with the objective of analysing the barriers to ART initiation revealed that the most frequent barriers among HIV-infected patients who did not receive ART were physician-related, followed by patient-related [51].

With respect to rapid ART initiation with $\mathrm{B} / \mathrm{F} / \mathrm{TAF}$, with high-quality evidence for adults and adolescents, the WHO recommends rapid ART initiation for all PLWH following an HIV diagnosis, defining rapid initiation as the start of ART within 7 days from the day of HIV diagnosis [13]. In our study, taking into account a conservative approach, we considered a period of 9 days from diagnosis to ART initiation, bearing in mind that 7 days would represent an ideal scenario that in most cases would be difficult to achieve. Nevertheless, the average time to B/F/TAF initiation in the early therapy strategy varied in the OWSA, demonstrating that initiating $\mathrm{B} / \mathrm{F} / \mathrm{TAF}$ at day 7 from diagnosis could avert 1063 new HIV cases.

Previous evaluations focused on our setting supported that the recommendations for ART initiation irrespective of CD4 count were expected to prevent 20,100 new HIV cases over 2 decades, compared with the strategy of ART initiation based on CD4 level, which had been followed up until then; this was considered a cost-effective policy [52].

The results of the present analysis support the contention that greater clinical benefits could be achieved if the period 
Table 4 One-way sensitivity analyses results

\begin{tabular}{|c|c|c|c|c|}
\hline Parameter & Base-case value & OWSA value & $\begin{array}{l}\text { Number of } \\
\text { avoided infec- } \\
\text { tions }\end{array}$ & Potential savings \\
\hline \multicolumn{3}{|l|}{ Base-case result } & 992 & $€ 322,856,609$ \\
\hline Time horizon & 20 years & 10 years & 327 & $€ 106,475,905$ \\
\hline \multirow{2}{*}{$\begin{array}{l}\text { Average time to therapy initiation in current } \\
\text { practice }\end{array}$} & \multirow[t]{2}{*}{35 days } & 44 days & 1319 & $€ 429,272,290$ \\
\hline & & 25 days & 662 & $€ 205,762,819$ \\
\hline $\begin{array}{l}\text { Average time to therapy initiation with } \mathrm{B} / \mathrm{T} / \mathrm{TAF} \text { in } \\
\text { early ART initiation strategy }\end{array}$ & 9 days & 7 days & 1063 & $€ 345,833,471$ \\
\hline \multirow[t]{3}{*}{ HIV lifetime cost } & \multirow[t]{3}{*}{$€ 325,408$} & $\begin{array}{l}€ 244,506 \\
(-25 \% \text { over BC) }\end{array}$ & 992 & $€ 242,142,457$ \\
\hline & & $\begin{array}{l}€ 406,760 \\
(+25 \% \text { over BC) }\end{array}$ & 992 & $€ 403,570,761$ \\
\hline & & $€ 519,280^{\mathrm{a}}$ & 992 & $€ 515,209,487$ \\
\hline Viral suppression for INSTIs per week & See Table 1 & $\mathrm{~B} / \mathrm{F} / \mathrm{TAF}$ viral suppression & 959 & $€ 312,164,507$ \\
\hline ART distribution & $\begin{array}{l}77.0 \% \text {-INSTIs, } 3.0 \%- \\
\text { NNRTIs, and } 20.0 \%- \\
\text { PIs }\end{array}$ & $\begin{array}{l}49.8 \% \text {-INSTIs, } 25.4 \%- \\
\text { NNRTIs, and } 24.8 \%- \\
\text { PIs }\end{array}$ & 1021 & $€ 332,079,609$ \\
\hline
\end{tabular}

$A R T$ antiretroviral therapy, $B C$ base case, $B / T / T A F$ bictegravir/emtricitabine/tenofovir alafenamide, HIV human immunodeficiency virus, INSTIS integrase strand transfer inhibitor, NNRTIs non-nucleoside reverse transcriptase inhibitor, OWSA one-way sensitivity analysis, PIs protease inhibitor

${ }^{\text {a }}$ Cost derived from health cost (€13,116/year) [43], considering an average age at diagnosis of 36 years [44] and 76 years of life expectancy [45]

between HIV diagnosis and ART initiation is reduced. Early therapy with B/F/TAF on day 9 from diagnosis instead of the current practice of ART initiation at day 35 could prevent up to 992 cases in the 20 years assessed in this simulation.

Based on the current published evidence, the B/F/TAF combination is considered an effective therapy with an acceptable tolerability profile, which makes it a convenient initial and ongoing treatment alternative for PLWH (including those co-infected with HBV). It is also the first non-pharmacologically boosted INSTI-based, triple-combination, single-treatment regimen suitable for use in patients with impaired renal function [17]. The results from our simulation suggest that rapid initiation with $\mathrm{B} / \mathrm{F} / \mathrm{TAF}$ is linked to epidemiologic and economic benefits in comparison with the delayed treatment initiation in current clinical practice.

There are some limitations to be considered in the interpretation of the results. One limitation of our study is that in the absence of other data, the per-act risk of HIV transmission was extracted from a study with a small sample size but with a rigorous and detailed collection of virological data [39]. The per-act transmission probability among HIVpositive patients depends largely on the viral suppression achieved with the combination of ART, and this parameter was varied in the OWSA, showing that it did not have a great impact on the results. The number of new HIV infections ranged between $992 \mathrm{HIV}$ infections prevented in the base case and 959 HIV infections prevented assuming B/F/TAF viral suppression for INSTIs. Another factor that could influence HIV transmission probability is the behaviour of individuals who become aware of their serological status. It is possible that these people modify their risky acts (i.e., using condoms, reducing sexual acts or not sharing needles); however, there is no quantitative evidence about the influence of these acts on the probability of HIV transmission for virologically unsuppressed individuals. Finally, our current study does not consider the potential drug resistance developed by HIV-positive individuals over the projected time horizon. The model methodology and the lack of robust evidence in the literature required simplifying assumptions about certain parameters that could impact the number and costs of new HIV infections. Regarding the HIV lifetime cost, in the absence of robust data for Spain, an HIV cost derived from a cost-effectiveness analysis was used. This cost included all health care inputs consumed and occupational losses generated during HIV disease, from the median age at diagnosis until death [32]. To analyse its impact on the results, an alternative HIV cost was tested in the OWSA, estimating the lifetime cost based on the annual healthcare cost by HIV patients in Spain obtained from a systematic review [43], and the life expectancy [44, 45]. 


\section{Conclusion}

Early ART initiation with B/F/TAF within 9 days of diagnosis with HIV infection is associated with a reduction in the number of new cases that could generate savings for the Spanish National Health System and society.

\section{Declarations}

Funding This study was funded by Gilead Sciences, Spain.

Conflicts of interest VE has received fees from Gilead Sciences, Janssen, Merck Sharp \& Dohme Corp. (MSD) and ViiV Healthcare for lectures, including service on speakers' bureaus. MG has received grants from ViiV Healthcare and fees from Gilead Sciences, Janssen and ViiV Healthcare for consulting work, participation in review activities and lectures, including service on speakers' bureaus. JAP has no conflicts of interest to declare. ET has received fees from Gilead Sciences for expert testimony. AC is a full-time employee of Gilead Sciences. MP and IO are employees of Pharmacoeconomics \& Outcomes Research Iberia (PORIB), a consultancy firm specializing in health technology assessment, which has received unconditional funding from Gilead Sciences.

Ethics approval Not applicable.

Consent to participate Not applicable.

Consent for publication Not applicable.

Availability of data and material All data used to develop the model are displayed in the manuscript.

Code availability Data are available from the corresponding author upon reasonable request.

Authors' contributions VE, MG, JAP and ET validated the parameters included in this analysis. MP performed the analysis. MP and IO drafted the manuscript. All authors participated in the interpretation of the results, and reviewed and approved the final manuscript.

Open Access This article is licensed under a Creative Commons Attribution-NonCommercial 4.0 International License, which permits any non-commercial use, sharing, adaptation, distribution and reproduction in any medium or format, as long as you give appropriate credit to the original author(s) and the source, provide a link to the Creative Commons licence, and indicate if changes were made. The images or other third party material in this article are included in the article's Creative Commons licence, unless indicated otherwise in a credit line to the material. If material is not included in the article's Creative Commons licence and your intended use is not permitted by statutory regulation or exceeds the permitted use, you will need to obtain permission directly from the copyright holder. To view a copy of this licence, visit http://creativecommons.org/licenses/by-nc/4.0/.

\section{References}

1. Fact sheet-World AIDS Day 2020. The Joint United Nations Programme on HIV/AIDS (UNAIDS). 2020. https://www.unaids.
org/sites/default/files/media_asset/UNAIDS_FactSheet_en.pdf. Accessed 22 Feb 2021.

2. GBD 2017 HIV collaborators. Global, regional, and national incidence, prevalence, and mortality of HIV, 1980-2017, and forecasts to 2030 , for 195 countries and territories: a systematic analysis for the Global Burden of Diseases, Injuries, and Risk Factors Study 2017. Lancet HIV. 2017;6(12):831-59. https://doi.org/10.1016/ S2352-3018(19)30196-1.

3. The Gap Report, 2014. The Joint United Nations Programme on HIV/AIDS (UNAIDS). 2014. https://www.refworld.org/docid/ 53f1e1604.html. Accessed 2 Mar 2020.

4. Understanding fast-track; accelerating action to end the AIDS epidemic by 2030 . The Joint United Nations Programme on HIV/AIDS (UNAIDS). 2015. http://www.unaids.org/sites/defau 1t/files/media_asset/201506_JC2743_Understanding_FastT rack_en.pdf. Accessed 23 Feb 2021.

5. Undetectable $=$ untransmittable. Public Health and HIV viral load suppression. The Joint United Nations Programme on HIV/AIDS (UNAIDS). 2018. https://www.unaids.org/sites/ default/files/media_asset/undetectable-untransmittable_en.pdf. Accessed 23 Feb 2021.

6. Guía de recomendaciones para el diagnóstico precoz del VIH en el ámbito sanitario. Ministerio de Sanidad, Consumo y Bienestar Social. Plan Nacional sobre SIDA [Ministry of Health]. 2014. https://www.mscbs.gob.es/ciudadanos/enfLesiones/enfTr ansmisibles/sida/docs/GuiaRecomendacionesDiagnosticoPreco zVIH.pdf. Accessed 2 Mar 2020.

7. Cevallos C, Verdejo J, Ruano MT, Petrova T, Ordobás M. Guía de recomendaciones para el diagnóstico precoz del VIH en el ámbito sanitario (Ministerio de Sanidad, Servicios Sociales e Igualdad, España, 2014): Implicaciones en la Comunidad de Madrid [Guidelines for early diagnosis of HIV-infection in healthcare settings (Ministry of Health, Social Services and Equality, Spain 2014): Implications for the Community of Madrid]. Revista Multidisciplinar del SIDA. 2017;5(12). https:// www.revistamultidisciplinardelsida.com/guia-de-recomendac iones-para-el-diagnostico-precoz-del-vih-en-el-ambito-sanit ario-ministerio-de-sanidad-servicios-sociales-e-igualdadespana-2014-implicaciones-en-la-comunidad-de-madrid/

8. Yeni PG, Hammer SM, Carpenter CC, Cooper DA, Fischl MA, Gatell JM, et al. Antiretroviral treatment for adult HIV infection in 2002: updated recommendations of the International AIDS Society-USA Panel. JAMA. 2002;288:222-35. https://doi.org/ 10.1001/jama.288.2.222.

9. Rubio R, Berenguer J, Miró JM, Antela A, Iribarren JA, González J, et al. Recomendaciones de GESIDA/Plan Nacional sobre el Sida respecto al tratamiento antirretroviral en pacientes adultos infectados por el virus de la inmunodeficiencia humana en el año 2002 [Recommendations of the Spanish AIDS Study Group (GESIDA) and the National Aids Plan (PNS) for antiretroviral treatment in adult patients with human immunodeficiency virus infection in 2002]. Enferm Infecc Microbiol Clin. 2002;20:244-303. https://doi.org/10.1016/s0213-005x(02) 72804-8.

10. Guideline on when to start antiretroviral therapy and on preexposure prophylaxis for HIV. World Health Organization; 2015. https://apps.who.int/iris/handle/10665/186275. Accessed 17 Feb 2021.

11. INSIGHT START Study Group, Lundgren JD, Babiker AG, Gor$\operatorname{din}$ F, Emery S, Grund B, Sharma S, et al. Initiation of antiretroviral therapy in early asymptomatic HIV infection. N Engl J Med. 2015;373:795-807. https://doi.org/10.1056/NEJMoa1506816.

12. Lundgren JD, Borges AH, Neaton JD. Serious non-AIDS conditions in HIV: benefit of early ART. Curr HIV/AIDS Rep. 2018;15:162-71. https://doi.org/10.1007/s11904-018-0387-y. 
13. Guidelines for managing advanced HIV disease and rapid initiation of antiretroviral therapy. World Health Organization. 2017. https://apps.who.int/iris/handle/10665/255884. Accessed $22 \mathrm{Feb}$ 2021.

14. FDA-Approved HIV Medicines. HIVinfo.nih.gov. 2021. https:// hivinfo.nih.gov/understanding-hiv/fact-sheets/fda-approved-hivmedicines. Accessed 17 Feb 2021.

15. New \& Events. HIV and AIDS. European Medicines Agency. 2021. https://www.ema.europa.eu/en/news-events/therapeuticareas-latest-updates/hiv-aids. Accessed 17 Feb 2021.

16. Ryom L, Cotter A, De Miguel R, Béguelin C, Podlekareva D, Arribas JR, et al. 2019 update of the European AIDS clinical society guidelines for treatment of people living with HIV version 10.0. HIV Med. 2020;21:617-24. https://doi.org/10.1111/hiv. 12878.

17. Deeks ED. Bictegravir/Emtricitabine/Tenofovir Alafenamide: a review in HIV-1 infection. Drugs. 2018;78:1817-28. https://doi. org/10.1007/s40265-018-1010-7.

18. GeSIDA. Documento de consenso de GeSIDA/Plan Nacional sobre el SIDA respect al tratamiento antiretroviral en adultos infectados por el virus de la inmunodeficiencia humana [GeSIDA/ National AIDS Plan consensus document on antiretroviral therapy in adults infected by the human immunodeficiency virus]. Grupo de Estudio del SIDA-SEIMC. 2020. https://gesida-seimc.org/wpcontent/uploads/2020/07/TAR_GUIA_GESIDA_2020_COMPL ETA_Julio.pdf. Accessed 12 May 2021.

19. Unidad de Vigilancia de VIH y Comportamientos de Riesgo. Vigilancia Epidemiológica del VIH y sida en España 2018: Sistema de Información sobre Nuevos Diagnósticos de VIH y Registro Nacional de Casos de Sida. Ministerio de Sanidad, Consumo y Bienestar Social. Plan Nacional sobre SIDA (Ministry of Health). 2019. https://www.mscbs.gob.es/ciudadanos/enfLesiones/enfTr ansmisibles/sida/vigilancia/doc/Informe_VIH_SIDA_2019_ 21112019.pdf. Accessed 7 Jan 2020.

20. Unidad de Vigilancia de VIH y Comportamientos de Riesgo. Vigilancia Epidemiológica del VIH y sida en España 2019: Sistema de Información sobre Nuevos Diagnósticos de VIH y Registro Nacional de Casos de Sida. Ministerio de Sanidad, Consumo y Bienestar Social. Plan Nacional sobre SIDA (Ministry of Health). 2020. https://www.mscbs.gob.es/ciudadanos/enfLesiones/enfTr ansmisibles/sida/vigilancia/Informe_VIH_SIDA_20201130.pdf. Accessed 24 Jun 2021.

21. HIV/AIDS surveillance in Europe 2017-2016 data. European Centre for Disease Prevention and Control/WHO Regional Office for Europe. 2017. https://www.ecdc.europa.eu/sites/default/files/ documents/20171127-Annual_HIV_Report_Cover\%2BInner.pdf. Accessed 14 Oct 2021.

22. Unidad de Vigilancia de VIH y Comportamientos de Riesgo. Vigilancia Epidemiológica del VIH y sida en España 2020: Sistema de Información sobre Nuevos Diagnósticos de VIH y Registro Nacional de Casos de Sida. Ministerio de Sanidad, Consumo y Bienestar Social. Plan Nacional sobre SIDA (Ministry of Health). 2021. https://www.mscbs.gob.es/ciudadanos/enfLesiones/enfTr ansmisibles/sida/vigilancia/Informe_VIH_SIDA_WEB.pdf. Accessed 21 Dec 2021.

23. Alejos B, Díez C, Galindo MJ, García-Fraile L, Gutiérrez F, Samperiz $\mathrm{G}$, et al. Temporal trends in time from HIV diagnosis to viral load suppression in CoRIS. XIX Congreso Nacional sobre el SIDA e ITS. Alicante: 3-5 April 2019.

24. Sax PE, Wohl D, Yin MT, Post F, DeJesus E, Saag M, et al. Tenofovir alafenamide versus tenofovir disoproxil fumarate, coformulated with elvitegravir, cobicistat, and emtricitabine, for initial treatment of HIV-1 infection: two randomised, double-blind, phase 3, non-inferiority trials. Lancet. 2015;385:2606-15. https:// doi.org/10.1016/S0140-6736(15)60616-X.
25. Sax PE, DeJesus E, Mills A, Zolopa A, Cohen C, Wohl D, et al. Co-formulated elvitegravir, cobicistat, emtricitabine, and tenofovir versus co-formulated efavirenz, emtricitabine, and tenofovir for initial treatment of HIV-1 infection: a randomised, doubleblind, phase 3 trial, analysis of results after 48 weeks. Lancet. 2012;379:2439-48. https://doi.org/10.1016/S0140-6736(12) 60917-9.

26. DeJesus E, Rockstroh JK, Henry K, Molina JM, Gathe J, Ramanathan $\mathrm{S}$, et al. Co-formulated elvitegravir, cobicistat, emtricitabine, and tenofovir disoproxil fumarate versus ritonavir-boosted atazanavir plus co-formulated emtricitabine and tenofovir disoproxil fumarate for initial treatment of HIV-1 infection: a randomised, double-blind, phase 3, non-inferiority trial. Lancet. 2012;379:2429-38. https://doi.org/10.1016/S0140-6736(12) 60918-0.

27. Gallant J, Lazzarin A, Mills A, Orkin C, Podzamczer D, Tebas P, et al. Bictegravir, emtricitabine, and tenofovir alafenamide versus dolutegravir, abacavir, and lamivudine for initial treatment of HIV-1 infection (GS-US-380-1489): a double-blind, multicentre, phase 3 , randomised controlled non-inferiority trial. Lancet. 2017;390:2063-72. https://doi.org/10.1016/S0140-6736(17) 32299-7.

28. Sax PE, Pozniak A, Montes ML, Koenig E, DeJesus E, Stellbrink $\mathrm{HJ}$, et al. Coformulated bictegravir, emtricitabine, and tenofovir alafenamide versus dolutegravir with emtricitabine and tenofovir alafenamide, for initial treatment of HIV-1 infection (GS-US-3801490): a randomised, double-blind, multicentre, phase 3, noninferiority trial. Lancet. 2017;390:2073-82. https://doi.org/10. 1016/S0140-6736(17)32340-1.

29. Walmsley SL, Antela A, Clumeck N, Duiculescu D, Eberhard A, Gutiérrez F, et al. Dolutegravir plus abacavir-lamivudine for the treatment of HIV-1 infection. N Engl J Med. 2013;369:1807-18. https://doi.org/10.1056/NEJMoa1215541.

30. Cahn P, Kaplan R, Sax PE, Squires K, Molina JM, Avihingsanon A, et al. Raltegravir $1200 \mathrm{mg}$ once daily versus raltegravir $400 \mathrm{mg}$ twice daily, with tenofovir disoproxil fumarate and emtricitabine, for previously untreated HIV-1 infection: a randomised, doubleblind, parallel-group, phase 3, non-inferiority trial. Lancet HIV. 2017;4:486-94. https://doi.org/10.1016/S2352-3018(17)30128-5.

31. Cohen C, Wohl D, Arribas JR, Henry K, Van Lunzen J, Bloch M, et al. Week 48 results from a randomized clinical trial of rilpivirine/emtricitabine/tenofovir disoproxil fumarate vs. efavirenz/ emtricitabine/tenofovir disoproxil fumarate in treatment-naive HIV-1-infected adults. AIDS. 2014;28:989-97. https://doi.org/ 10.1097/QAD.0000000000000169.

32. Reyes-Urueña J, Campbell C, Diez E, Ortún V, Casabona J. Can we afford to offer pre-exposure prophylaxis to MSM in Catalonia? Cost-effectiveness analysis and budget impact assessment. AIDS Care. 2018;30:784-92. https://doi.org/10.1080/09540121.2017. 1417528.

33. Proyecciones de población. Población y fenómenos demográficos nacionales: serie 2018-2068. Instituto Nacional de Estadística (National Statistics Institute). 2019. https://www.ine.es. Accessed 7 Jan 2020.

34. Country factsheets Spain. The Joint United Nations Programme on HIV/AIDS (UNAIDS). 2018. https://www.unaids.org/es/regio nscountries/countries/spain. Accessed 7 Jun 2020.

35. Informe 2019. Alcohol, tabaco y drogas ilegales en España. Observatorio Español de las Drogas y las Adicciones. 2019. http:// www.pnsd.mscbs.gob.es/profesionales/sistemasInformacion/infor mesEstadisticas/pdf/2019OEDA-INFORME.pdf. Accessed 30 Jan 2020.

36. Díaz A. Actualización epidemiológica española de los objetivos 2020. Revista Multidisciplinar del SIDA. 2020;8:11-2. 
37. Ndiaye B, Ould-Kaci K, Salleron J, Bataille P, Bonnevie F, Cochonat $\mathrm{K}$, et al. Characteristics of and outcomes in HIVinfected patients who return to care after loss to follow-up. AIDS. 2009;23:1786-9. https://doi.org/10.1097/QAD.0b013e3283 $2 \mathrm{e} 3469$.

38. Garriga C, de Olalla PG, Miró JM, Ocaña I, Knobel H, Barberá MJ, et al. Mortality, causes of death and associated factors relate to a large HIV population-based cohort. PLoS ONE. 2015;10: e0145701. https://doi.org/10.1371/journal.pone.0145701.

39. Supervie V, Assoumou L, Breban R, Lert F, Costagliola D, Pialoux G, et al. Risk of HIV transmission during combined ART initiation for HIV-infected persons with severe immunosuppression. J Antimicrob Chemother. 2017;72:3172-6. https://doi.org/ 10.1093/jac/dkx276.

40. Wenz B, Nielsen S, Gassowski M, Santos-Hövener C, Cai W, Ross RS, et al. High variability of HIV and HCV seroprevalence and risk behaviours among people who inject drugs: results from a cross-sectional study using respondent-driven sampling in eight German cities (2011-14). BMC Public Health. 2016;16:927. https://doi.org/10.1186/s12889-016-3545-4.

41. Belgian national report on drugs 2013. OD Public Health and Surveillance, Scientific Institute of Public Health. 2013. https:// infordrogues.be/wp-content/uploads/2014/05/Plettinckx_2013_ EN.pdf. Accessed 8 Jan 2020.

42. Bayoumi AM, Zaric GS. The cost-effectiveness of Vancouver's supervised injection facility. CMAJ. 2008;179:1143-51. https:// doi.org/10.1503/cmaj.080808.

43. Trapero-Bertran M, Oliva-Moreno J. Economic impact of HIV/ AIDS: a systematic review in five European countries. Health Econ Rev. 2014;4:15. https://doi.org/10.1186/s13561-014-0015-5.

44. Indicadores de mortalidad. Esperanza de vida al nacimiento 2019. Instituto Nacional de Estadística (National Statistics Institute). 2019. https://www.ine.es. Accessed 29 Oct 2020.

45. Oliva-Moreno J, Trapero-Bertran M. Economic impact of HIV in the highly active antiretroviral therapy era: reflections looking forward. AIDS Rev. 2018;20:226-35. https://doi.org/10.24875/ AIDSRev.M17000011.
46. Encuesta Hospitalaria de pacientes con infección por el VIH. Resultados 2019. Ministerio de Sanidad, Consumo y Bienestar Social. Plan Nacional sobre SIDA (Ministry of Health). 2019. https://www.mscbs.gob.es/ciudadanos/enfLesiones/enfTransmi sibles/sida/vigilancia/Encuesta_hospitalaria2019.pdf. Accessed 29 Oct 2020.

47. Mayer K, Gazzard B, Zuniga JM, Amico KR, Anderson J, Azad Y, et al. Controlling the HIV epidemic with antiretrovirals: IAPAC consensus statement on treatment as prevention and preexposure prophylaxis. J Int Assoc Provid AIDS Care. 2013;12:208-16. https://doi.org/10.1177/2325957413475839.

48. Yoshimura K. Current status of HIV/AIDS in the ART era. J Infect Chemother. 2017;23:12-6. https://doi.org/10.1016/j.jiac.2016.10. 002 .

49. Guidelines for treatment of HIV-positive adults in Europe 2017. European AIDS Clinical Society. 2018. http://www.eacsociety. org/guidelines/eacs-guidelines/eacs-guidelines.html. Accessed 16 Mar 2021.

50. Panel de expertos de GeSIDA y Plan Nacional sobre el Sida. Documento de consenso de GeSIDA/Plan Nacional sobre el Sida respecto al tratamiento antirretroviral en adultos infectados por el virus de la inmunodeficiencia humana. Grupo de estudio del SIDA-SEIMC. 2017. http://gesida-seimc.org/category/guias-clini cas/antirretroviral-vigentes/. Accessed 16 Mar 2021.

51. Viciana-Fernández P, Falcó V, Castaño M, de los Santos-Gil I, Olalla-Sierra J, Hernando A, et al. Barriers to ART initiation in HIV infected subjects and with treatment indication in Spain. Why don't they start their treatment? Bridgap Study. Enferm Infecc Microbiol Clin. 2015;33(6):397-403. https://doi.org/10.1016/j. eimc.2014.06.012.

52. Kasaie P, Radford M, Kapoor S, Jung Y, Novoa BH, Dowdy D, et al. Economic and epidemiologic impact of guidelines for early ART initiation irrespective of CD4 count in Spain. PLoS ONE. 2018;13: e0206755. https://doi.org/10.1371/journal.pone.02067 55 . 